\title{
THE MOTIVATION AND READINESS OF INSTRUMENTATION IN CULTIVATING INTEREST OF FAMILY BUSINESS SUCCESSOR
}

\author{
I Gusti Bagus Yosia Wiryakusuma \\ Ciputra University
}

\begin{abstract}
Family business importantly contributes to the economy; however, family business also has several problems. One of the problems that often befall family business is succession planning. Not every successor or succeeding generation are interested in continuing the family business. The aim of this study is to identify the effect of the motivation and readiness of the instrumentation on the interest of the successor in continuing the family business. The methods used in this study is regression analysis with a sample of 152 respondents. The results show that motivation and the readiness of instrumentation significantly affects the successor's interest to continue the family business.
\end{abstract}

Keywords: motivation, instrumentation readiness, interest, family business, succession

\section{BACKGROUND}

Family business is a business owned and operated by a family and has an important contribution to a country's economy (Septiani \& Mustamu, 2014). According to Pricewaterhouse Coopers (PwC; 2014), a business is considered a family business when at least one family member is part of the business management team and has a minimum of $25 \%$ ownership of the business. Approximately $60 \%$ of public companies in East Asia comprises of family business. A survey done by PwC (2014) showed that more than $95 \%$ of businesses in Indonesia is family owned. The important contribution of family businesses in Indonesia can be observed from the level of contribution as high as 25\% to GDP (PwC, 2014). Based on this survey, it can be said that if family business experience problems, it will impact Indonesia's economy.

"Corresponding Author.

e-mail: bagus.yosia@ciputra.ac.id
Ciputra University is one of the universities that pays attention to family businesses. This is evident from the presence of the Family Business Community in Ciputra University, which is a community that consists of university students who has the interest and mentored to continue their family business. One of the main problems in family business is the business's succession planning, as mentioned by Michael and Kammerlander (2015) who stated that family business has its own unique issue in succession planning. This is also supported by the PwC (2014) survey that indicates approximately $60 \%$ of family business has a successor who wants to continue the business. This condition also happens to family businesses that is part of the Family Business Community of Ciputra University. Therefore, the successor's interest to continue the family business should be a priority that is attended to in the family business management. The continuation of the fam- 
I Gusti Bagus Yosia Wiryakusuma / The Motivation and Readiness of Instrumentation in Cultivating Interest of Family Business Successor / JEE, Vol. 9, No. 1, March 2020, pp 23-28

ily business depends on the succession process that runs from generation to generation (Chan, 2019). There are several reasons that makes successors would want to continue the family business, some of them are motivation and the readiness of the instrumentation.

The successor's motivation could form or determine the level of involvement of the successor in taking his/her role within the family business (Wijaya, 2014). Motivation is one of the forces that could generate someone's enthusiasm and diligence to do something (Wijaya, 2014). The greater the motivation of the successor, the greater the interest to continue the family business. Besides motivation, the readiness of the successor to continue the family business also has an effect on interest. Motivation is a factor that causes impartation and supports human behaviour; hence humans can work diligently to attain their goal (Hasibuan, 2013). According to Mangkunegara (2002), motivation is divided into 2 , which are internal and external motivation. Internal motivation is motivation that originates from one self, whilst external motivation is motivation that originates from external source, such as supporting environment. The indicators used in this research is achievement, the work itself, acknowledgment, responsibility, development of the individual's potential, salary, policy and administration, working condition, quality of supervisor, collegial relationship.

Readiness refers to the individual's preparedness of self to pursue something that they want (Nitisusastro, 2009). When instrumentation readiness is highly satisfactory, it will affect one's interest. Therefore, it can be said that when successor has instrumentation readiness, the successor will have self-confidence thus generating interest to continue the family business. A study by Diken and Erdirencelebi (2016) states that the role of parents that has instrumentation readiness significantly impact the formation of successor's interest. Readiness is the one's self-readiness when entering the field that they pursue. Instrumentation readiness is the required provision to run the business (Nitisusastro, 2009). The indicators of instrumentation readiness in this study are the readiness of mental, knowledge, and resource.

According to Rees (2017), interest is one of the most important determinants of someone's behaviour. Interest is a combination of the person's subjective norm, attitude, and controlled action. The indicators of interest in this study is subjective norm, attitude, and controlled action. Based on this, this study will discuss the effect of motivation and instrumentation preparedness on successor's interest to continue family business.

\section{METHODS}

The sample population of this study is the entire Ciputra University students who are registered under the Family Business Guild, which has a total of 246 people. The technique used to sample is probability sampling; simple random sampling. The research sample will be chosen randomly and each respondent has the same probability to be sampled (Sugiyono, 2017). The Slovin formula is used to obtain the number of samples required. The sample in this study is 152 respondents.

The regression analysis is used in this study with the following formula:

$\mathrm{Y}=\alpha+\beta_{1} X_{1}+\beta_{2} X_{2}+\varepsilon$

Where:

$Y=$ Interest to continue the family business

$X_{1}=$ Motivation

$X_{2}=$ Instrumentation Readiness 
$\alpha=$ Constant

$\beta_{1}=$ Motivation Coefficient

$\beta_{2}=$ Instrumentation Readiness Coefficient

$\varepsilon=$ Error

\section{RESULTS AND DISCUSSION}

Based on the conducted research, the result of the descriptive statistics is shown below:

Table 1 Descriptive Data

\begin{tabular}{lccc}
\hline & Motivation & $\begin{array}{c}\text { Instrumentation } \\
\text { Readiness }\end{array}$ & Interest \\
\hline Mean & 3.49 & 3.43 & 3.51 \\
Standard Deviation & 1.11 & 1.31 & 1.33 \\
Minimum & 1.40 & 1.00 & 1.00 \\
Maximum & 5.00 & 5.00 & 5.00 \\
Count & 152 & 152 & 152 \\
\hline
\end{tabular}

Source: Processed Data (2020)

Based on Table 1, the mean score of motivation, instrumentation readiness, and interest are $3.49,3.43$, and 3.51 respectively. The variables of motivation, instrumentation readiness, and interest have the standard deviation of $1.11,1.31$, and 1.33 respectively. The motivation variable has the maximum score of 5 and minimum score of 1.4. The instrumentation readiness and interest have the maximum score of 5 and minimum score of 1 . Each of the variables has 152 respondents.

Table 2 Regression Statistics

\begin{tabular}{lr}
\hline \multicolumn{2}{c}{ Regression Statistics } \\
\hline Multiple R & 0.95 \\
R Square & 0.91 \\
Adjusted R Square & 0.91 \\
Standard Error & 0.41 \\
Observations & 152 \\
\hline
\end{tabular}

Source: Processed Data (2020)
According to Table 2, the Multiple $\mathrm{R}$ is 0.95, this shows that the linear relationship between dependent and independent variable has a strong relationship. The $\mathrm{R}$ Square is close to 1 with the score of 0.91 , which means that the model has a good fit. The Adjusted $\mathrm{R}$ Square score is not much different at 0.91 . Based on Table 2, the Standard Error score is 0.41 , which means that it is smaller than the Standard Deviation score in Table 1. This means that the regression model used is more accurate.

Table 3 ANOVA

\begin{tabular}{lccccc}
\hline & df & SS & MS & F & $\begin{array}{c}\text { Significance } \\
\text { F }\end{array}$ \\
\hline Regression & 2 & $243 \mathrm{~F}, 516$ & 121,758 & 727,8 & $1,27 \mathrm{E}-77$ \\
Residual & 149 & 24,927 & 0,167 & & \\
Total & 151 & 268,443 & & & \\
\hline
\end{tabular}

Source: Processed Data (2020)

Based on Table 3, the Significance $F$ score is 1.27E-77 which is smaller than the 95\% confidence interval. If the Significance $F$ score is smaller than the confidence interval, it can be concluded that motivation and instrumentation readiness both significantly affects interest to continue family business.

Table 4 Regression Analysis

\begin{tabular}{lcccccc}
\hline & Coefficients & $\begin{array}{c}\text { Standard } \\
\text { Error }\end{array}$ & t Stat & P-value & $\begin{array}{c}\text { Lower } \\
\mathbf{9 5 \%}\end{array}$ & $\begin{array}{c}\text { Upper } \\
\mathbf{9 5 \%}\end{array}$ \\
\hline Intercept & $-0,31$ & 0,11 & $-2,80$ & 0,005802 & $-0,53$ & $-0,09$ \\
Motivation & 0,66 & 0,07 & 9,95 & $3,28 \mathrm{E}-18$ & 0,53 & 0,79 \\
Instrumentation & 0,43 & 0,06 & $\mathbf{7 , 6 1}$ & $3,03 \mathrm{E}-12$ & 0,32 & 0,55 \\
Readiness & & & & & & \\
\hline
\end{tabular}

Source: Process Data (2020)

Based on the regression analysis, the results are shown in Table 4. The $p$ value of motivation and instrumentation readiness are both less than the $95 \%$ confidence interval, which means that both variables significantly affects interest to continue the family business. 
I Gusti Bagus Yosia Wiryakusuma / The Motivation and Readiness of Instrumentation in Cultivating Interest of Family Business Successor / JEE, Vol. 9, No. 1, March 2020, pp 23-28

\section{DISCUSSION}

According to this research, the results indicate that: (1) motivation significantly affects the successor's interest to continue the family business, and (2) the instrumentation readiness significantly affects the successor's interest to continue the family business. Good motivation and the instrumentation readiness will make the successor be more interested to continue the family business. This is supported by previous existing research.

The Impact of Motivation on the Interest to Continue the Family Business

Based on the regression analysis above, the results show that motivation affects the successor's interest to continue the family business. Motivation determines the intention of the successor to continue the family business or not. Good motivation would increase the successor's interest to continue the family business and vice versa. Diken and Erdirencelebi (2016) stated that parents have a significant influence toward the development of interest of their children. Parents' role to motivate their children to continue the business that has been built across generations is one of the most important factors. A study by Wijaya (2014) found that the parental encouragement is one of the external factors that could create interest in successors to continue the family business. Laurence and Mustamu (2015) stated that the discomfort of the successors will cause internal conflict. The discomfort of the successor's is one of the reasons why the predecessor generation are less trusting, which causes lack of motivation from the successors. This is supported by a study done by Chan (2019) that states that conflict caused by envy between successors fuels the wrong motivation to continue the family business. High motivation will create higher work productivity (Purnama, 2008). High level of productivity will certainly be the consideration of the predecessor generation in deciding successor.

\section{The Effect of Instrumentation Readiness on the Interest to Continue the Family Business}

The instrumentation readiness has an effect on the interest to continue the family business. The role of parents which influence the instrumentation readiness significantly influence the development of interest in successors (Diken \& Erdirencelebi, 2016). This indicates that the more ready the successors are in continuing the family business, the greater the interest of the successors to continue the family business. A high readiness of self will create strong self-confidence. Based on this self-confidence that successors will become more interested to continue the family business. Chan (2019) states that a successor should posses the readiness before taking on a role in the family business. This finding is congruent with Laurence and Mustamu's (2015) study, which stated that leadership in the business requires the readiness of the successor. Tjiang (2014) stated that the readiness of the successor is very important to prepare the successor. Well-prepared successors will make succession process run smoothly (Christopher, 2014).

This research aims to identify the effect of motivation and instrumentation readiness on the interest of successor to continue the family business. After analysing the research data of 152 respondents, the results of this study can be concluded as follows. Motivation affects the successor's interest to continue the family busi- 
ness. In addition, the instrumentation readiness affects the successor's interest to continue the family business.

\section{REFERENCES}

Chan, H. C. (2019). Manajemen Konflik dalam Perencanaan Suksesi Perusahaan Keluarga PT Mitra Indah Lestari. AGORA, 7(1).

Christopher, C. (2014). Analisis Deskriptif Proses Sukesi pada Perusahaan Bidang Mebel di Gresik. Agora, 2(2), 1380-1386.

Diken, A. \& Erdirençelebi, M. (2016). The Role of Parents in Teaching Entrepreneurship Culture to Their Children in Family Business. International Journal of Industrial and System Engineering, 10 (7), 24232432.

Hasibuan, M.S.P. 2013. Manajemen Sumber Daya Manusia. Jakarta: PT Bumi Aksara

Laurence, L. \& Mustamu, R. H. (2015). Manajemen Konflik dalam Perencanaan Suksesi Perusahaan Keluarga di Bidang Ekspedisi di Surabaya. AGORA, 3(1), 725-735.

Lee, K. S., Lim, G. H., \& Lim, W. S. (2003). Family Business Succession: Appropriation Risk and Choice of Successor. Academy of Management Review, 23(4), 657-666.
Mangkunegara, A.P. (2002). Manajemen Sumber Daya Manusia. Bandung: PT Remaja Rosda Karya.

Michel, A. \& Kammerlander, N. (2015). Trusted advisor in family business's succession-planning process-An agency perspective. Journal of Family Business Strategy, 6(1), 4557.

Nitisusastro, M. (2009). Kewirausahaan \& Manajemen Usaha Kecil. Bandung: PT Alfabeta.

Purnama, R. (2008). Pengaruh Motivasi Kerja Terhadap Produktivitas Kerja Karyawan pada Bagian Produksi CV. Epsilon Bandung. Jurnal Strategic, 7(14), 58-72.

Septiani, V. \& Mustamu, R. H. (2014). Perencanaan Suksesi pada Perusahaan Keluarga PT Gading Murni. AGORA, 2(2), 890897.

Sugiyono. (2017). Metode Penelitian Kuantitatif, Kualitatif dan R\&D. Bandung: Alfabeta.

Tjiang, C. G. H. (2014). Studi Deskriptif Perencanaan Suksesi Kepemimpinan pada Perusahaan Keluarga di Bidang Konstruksi di Sidoarjo. Agora, 2(2), 1369-1379.

Wijaya, C. T. (2014). Faktor-Faktor Motivasional yang Mengklasifikasi Keterlibatan Mahasiswa dalam Mengambil Peran pada Bisnis Keluarga. AGORA, 2(2), 743-748. 